\title{
Studies on the Scorpaenoid Fishes of Japan. II. Statistical Observations on Sebastodes inermis (C. et V.)*
}

\author{
Kiyomatsu MATSUBARA
}

\author{
(The Imperial Fisheries Institute, Tôkyô)
}

The splitting of a species of scorpaenoid fish, Sebastodes inermis (C. \& V.), into four, viz., S. inermis, S. ventricosus T. \& S., S. güntheri J. \& St., and $S$. tokionis J. \& St., has been adopted by several authors. On the other hand, the reduction of these four to two, namely, S. inermis and S. tokionis, was done by Jordan and $\mathrm{Hubbs}^{i}$; and even the amalgamation of all these four to one, $S$. inermis, was suggested by Tanaka. ${ }^{16)}$

The paramount importance of an exact method of attacking the problem and an abundant supply of the material to work with is obvious. The author is greatly indebted to Dr. A. Terao and to Dr. M. Tauti for their kind guidance in applying a method, which is quite distinct from the hitherto used, to his material. He is also much obliged to the stuff of the Tyôsen. Fisheries Experimental Station for a loan of specimens from Huzan to supplement his collection of the fishes from Simonoseki, Misaki, Tôkyô Bay, Bôsyû, Rikutyû and Hakodate.

In passing, it may be mentioned that the specimens amounting to 198 in number were found to vary from one to seven years in age and to cover the entire range of the variations recorded by the former authors, including some intermediate forms between any two of the above-mentioned four. Osteological examinations did not reveal any point which would go to distinguish the four species. Nor were my results consistent with the view that the specimens at my disposal are referable to the two, $S$. inermis and $S$. tokionis.

It would not be sufficient to leave the argument at this stage of documentation. Still, one would insist that the four-fold splitting of the species is tenable. It is evident that one should weigh the relative value of the deviations and ascertain presence or absence of incipient tendency of divergence against the whole set of the samples if one would settle the question conclusively. It may be remarked parenthetically that the ordinary procedure

* Contributions frona the Zoological Laboratory, Imperial Fisheries Institute (Tôkyô), No. 39. The expense of this work has been partly defrayed by the researih fund from "Nihon G.skujutsu Shinkokai" (Foundation for the Promotion of Scientific and Industrial Research of Japan). 


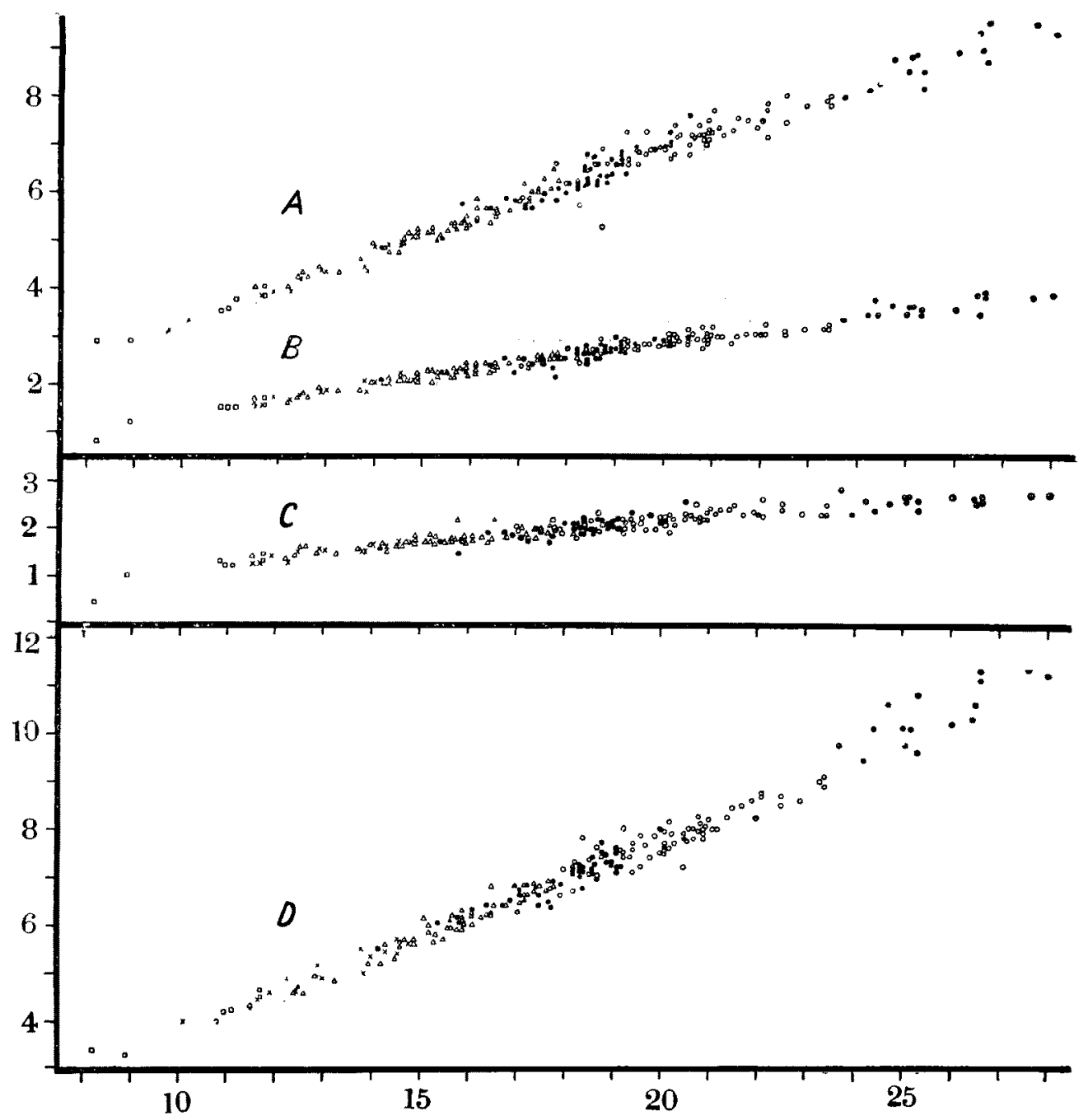

Fig. 1. Showing dimension (in $\mathrm{cm}$ ) of body parts in relation to body length of Sebastodes inermis. $A$, length of head; $B$, length of maxillary ; $C$, diameter of orbit : $D$, depth of body. Individuals marked with $\square$, one year old; $x$, two years; $\Delta$, three years; $\bullet$, four years; $O$, five years ; $\Theta$, six years ; $\oplus$, seven years.

of ichthyology falls short of exactness in giving the variations of various parts of body since such items as diameter of orbit, length of maxillary, etc. are referred to head length which is again defined in terms of reverse ratio to body length. Consequently the net measurement of all the body parts utilized for taxonomy, viz., length of head, length of maxillary, diameter of orbit, depth of body, length of the longest dorsal spine, length of second 


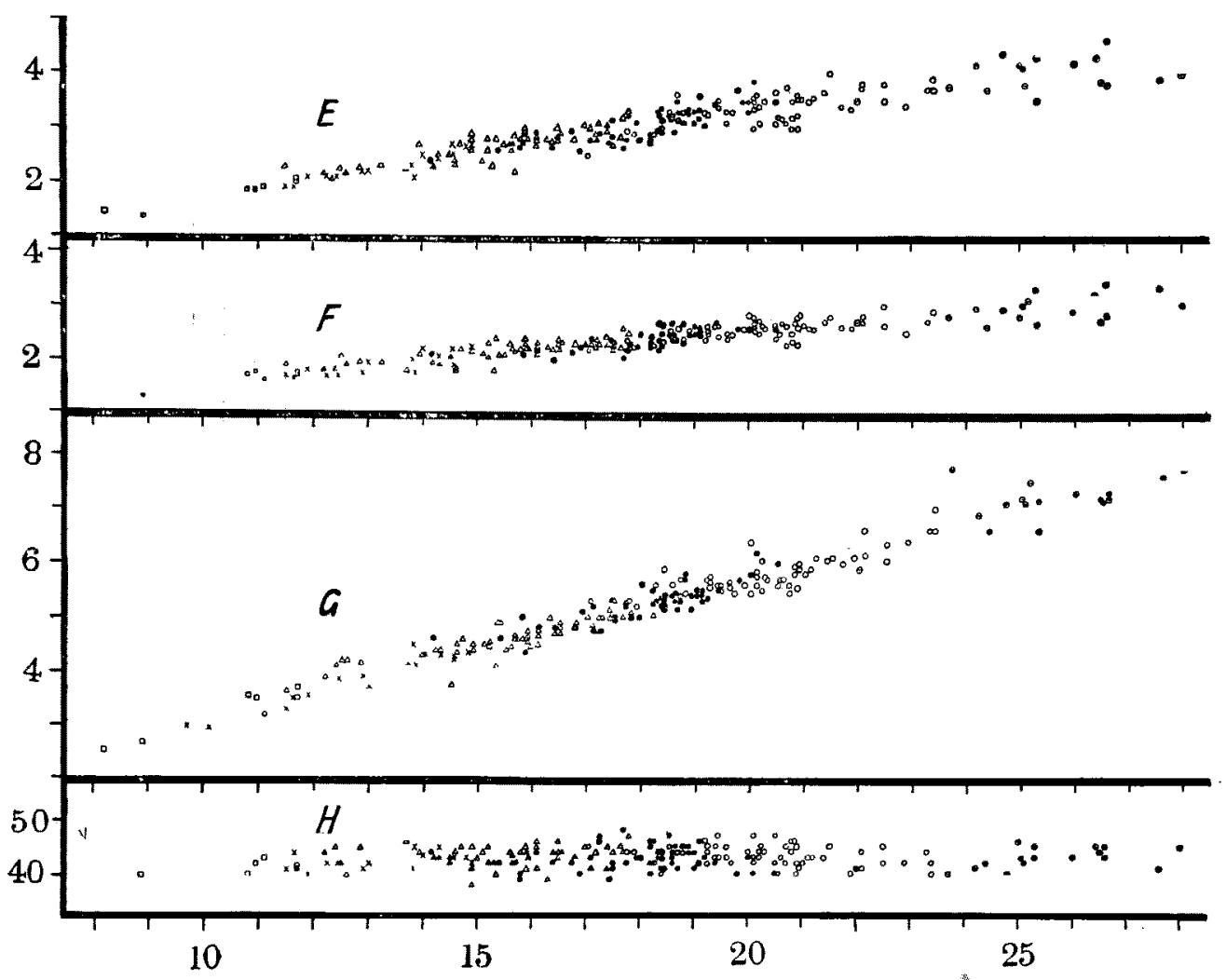

Fig. 2. Same as in Fig. 1 with the same yearly symbols. $E$, length of longest dorsal spine; $F$, length of second anal spine; $G$, length of pectoral fin; $H$, number of seales on lateral line.

Table 1. Frequencies of individuals of Sebastodes inermis.

Locality: $A$, Hakodate; $B$, Miyako; $C$, Mito; $D$, Kominato; $E$, Mera ; $F$, Tôkyô Bay ; $G$, Misaki ; $H$, Simonoseki ; $I$, Huzan.

Age: III, three years, IV, four years, and $v$, five years old.

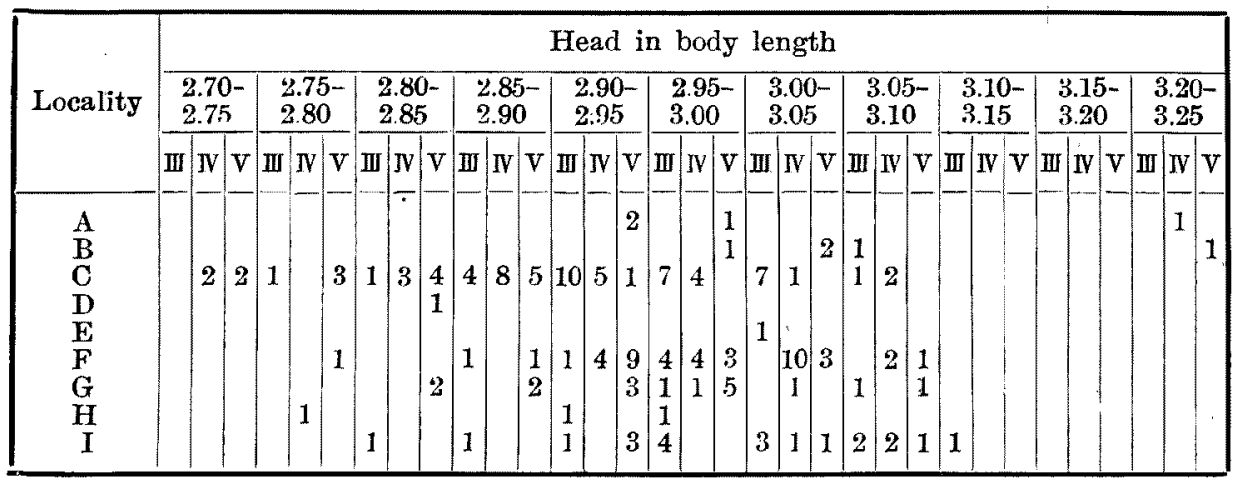




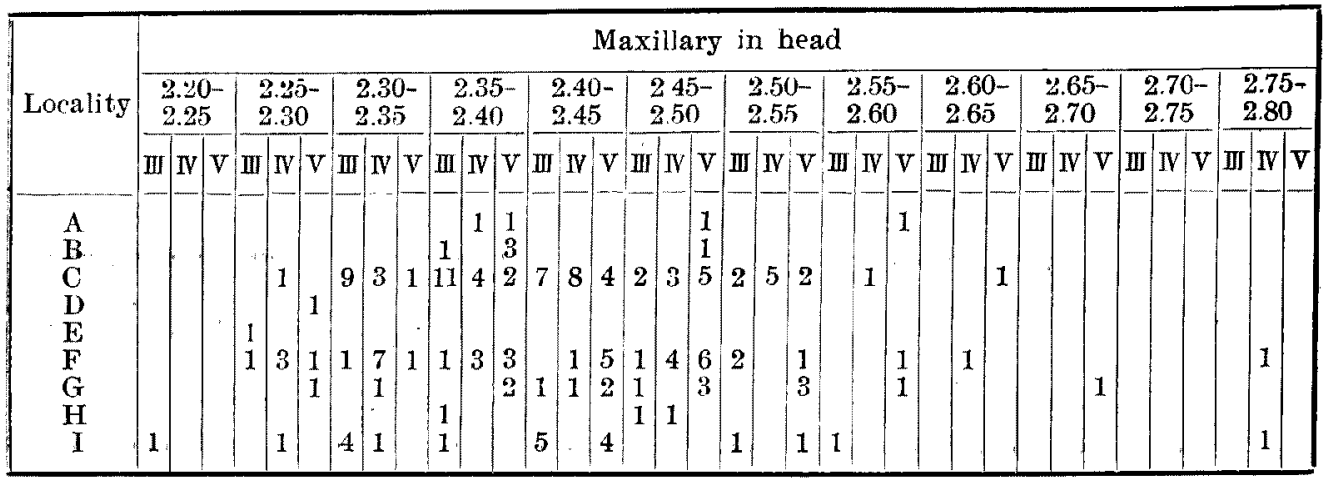

\begin{tabular}{|c|c|c|c|c|c|c|c|c|c|c|c|c|c|c|c|c|c|c|c|c|c|c|c|c|c|c|c|}
\hline \multirow{3}{*}{ Locality } & \multicolumn{27}{|c|}{ Diameter of orbit in head } \\
\hline & \multicolumn{3}{|c|}{$2.60-2.70$} & \multicolumn{3}{|c|}{$2.70-2.80$} & \multicolumn{3}{|c|}{$2.80-2.90$} & \multicolumn{3}{|c|}{$2.90-3.00$} & \multicolumn{3}{|c|}{$3.00-3.10$} & \multicolumn{3}{|c|}{$3.10-3.20$} & \multicolumn{3}{|c|}{$3.20-3.30$} & \multicolumn{3}{|c|}{$3.30-3.40$} & \multicolumn{3}{|c|}{$3.40-3.50$} \\
\hline & III & IV & $\mathrm{V}$ & III & $\mathrm{NV}$ & $V$ & III & IV & $\mathrm{V}$ & III & IV & $\mathrm{V}$ & III & IV & $V$ & III & $N$ & V & III & $N$ & $\mathrm{~V}$ & III & IV & $\mathrm{V}$ & III. & IV & $v$ \\
\hline $\begin{array}{c}\mathrm{A} \\
\mathrm{B} \\
\mathrm{C} \\
\mathrm{D} \\
\mathrm{E} \\
\mathrm{F} \\
\mathrm{G} \\
\mathrm{H} \\
\mathrm{I}\end{array}$ & 2 & & & 1 & & & $\begin{array}{l}1 \\
1\end{array}$ & 2 & & 3 & $\begin{array}{l}1 \\
1\end{array}$ & $\begin{array}{l}1 \\
3 \\
1\end{array}$ & $\begin{array}{l}1 \\
1 \\
2\end{array}$ & $\begin{array}{l}2 \\
1 \\
1\end{array}$ & $\begin{array}{l}1 \\
5 \\
3\end{array}$ & $\begin{array}{l}1 \\
3\end{array}$ & $\begin{array}{l}1 \\
7\end{array}$ & $\begin{array}{l}1 \\
2 \\
6 \\
1 \\
\\
4 \\
5\end{array}$ & 1 & 3 & $\begin{array}{l}2 \\
3\end{array}$ & 3 & 1 & 3 & & ' & 3 \\
\hline
\end{tabular}

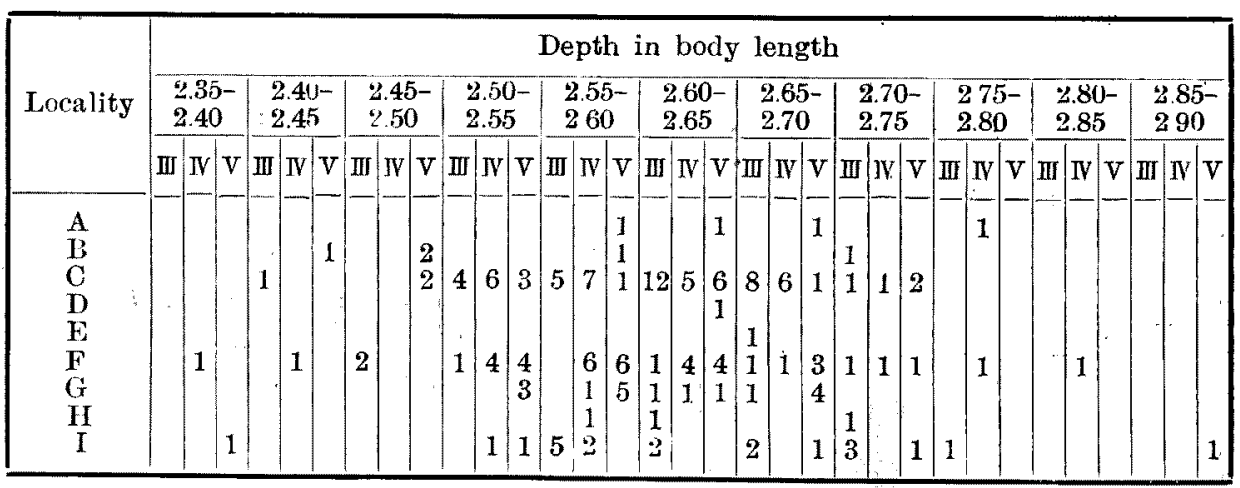




\begin{tabular}{|c|c|c|c|c|c|c|c|c|c|c|c|c|c|c|c|c|c|c|c|c|c|}
\hline \multirow{3}{*}{ Locality } & \multicolumn{21}{|c|}{ Longest dorsal spine in head } \\
\hline & \multicolumn{3}{|c|}{$1.7-1.80$} & \multicolumn{3}{|c|}{$1.80-1.90$} & \multicolumn{3}{|c|}{$1.90-2.00$} & \multicolumn{3}{|c|}{$2.00-2.10$} & \multicolumn{3}{|c|}{$2.10-2.20$} & \multicolumn{3}{|c|}{$220-2.30$} & \multicolumn{3}{|c|}{$3.30-2.40$} \\
\hline & III & $N$ & $\mathrm{~V}$ & III & IV & $\mathrm{V}$ & III & $\mathrm{T}$ & $\mathrm{V}$ & III & IV & $\mathrm{V}$ & III & IV & $\nabla$ & III & IV & $\mathrm{V}$ & IIII & IV & $V$ \\
\hline $\begin{array}{c}\mathbf{A} \\
\mathbf{B} \\
\mathbf{C} \\
\mathbf{D} \\
\mathbf{E} \\
\mathbf{F} \\
\mathbf{G} \\
\mathbf{H} \\
\mathbf{I}\end{array}$ & $\begin{array}{l}1 \\
1\end{array}$ & 1 & & $\frac{1}{5}$ & $\begin{array}{l}1 \\
1\end{array}$ & $\begin{array}{l}1 \\
2\end{array}$ & $\begin{array}{r}11 \\
1 \\
2 \\
1 \\
1 \\
2\end{array}$ & $\begin{array}{l}4 \\
1 \\
2\end{array}$ & $\begin{array}{l}6 \\
3\end{array}$ & $\begin{array}{l}1 \\
4\end{array}$ & $\begin{array}{l}1 \\
5\end{array}$ & $\begin{array}{l}6 \\
3\end{array}$ & $\begin{array}{l}1 \\
2\end{array}$ & $\begin{array}{l}3 \\
1\end{array}$ & $\begin{array}{l}3 \\
5 \\
4\end{array}$ & 1 & 4 & $\begin{array}{l}2 \\
1\end{array}$ & & & 1 \\
\hline
\end{tabular}
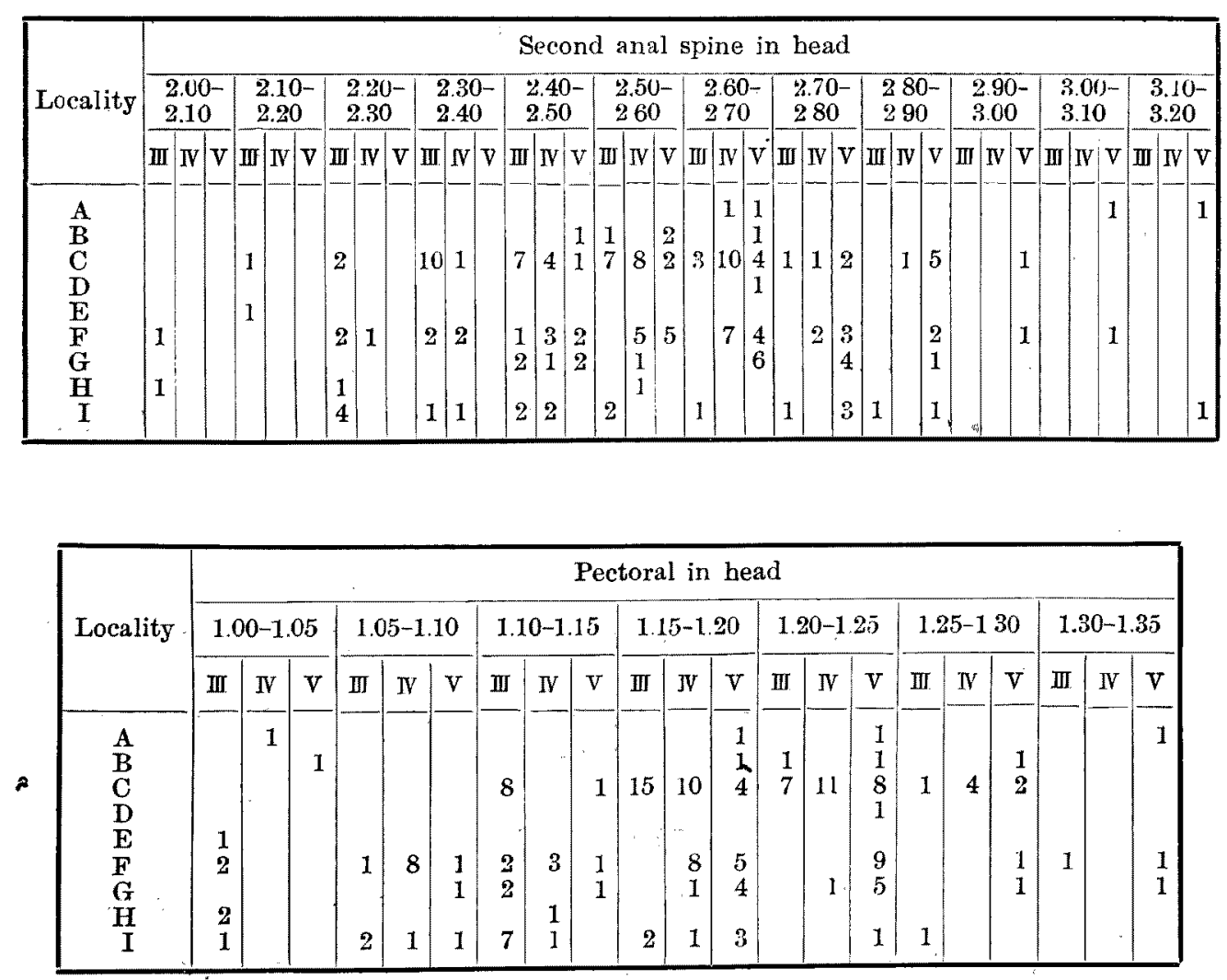


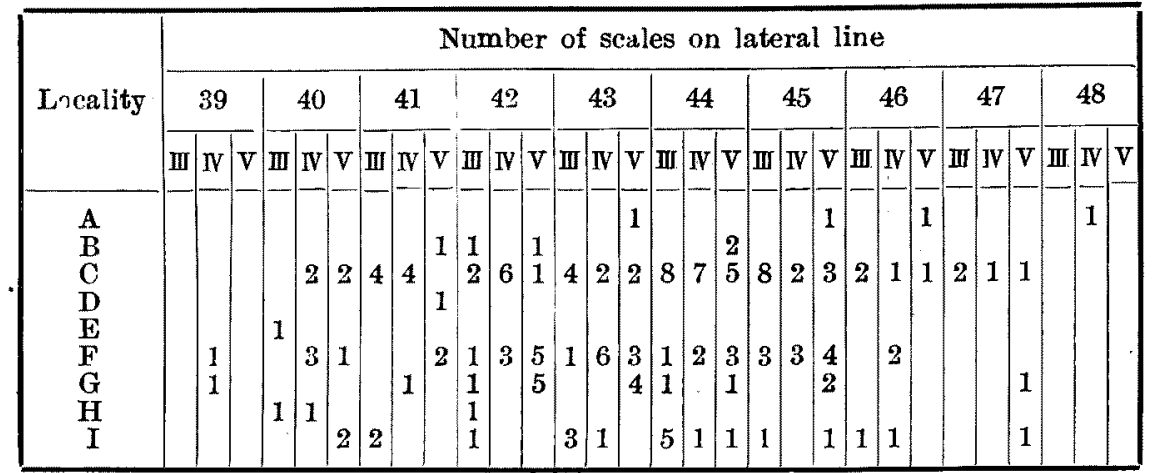

\begin{tabular}{|c|c|c|c|c|c|c|c|c|c|c|c|c|c|c|c|c|c|c|c|c|c|c|c|c|}
\hline \multirow{3}{*}{ Locality } & \multicolumn{12}{|c|}{ Number of soft rays of dorsal fin } & \multicolumn{12}{|c|}{ Number of soft rays of anal fin } \\
\hline & \multicolumn{3}{|c|}{13} & \multicolumn{3}{|c|}{14} & \multicolumn{3}{|c|}{15} & \multicolumn{3}{|c|}{16} & \multicolumn{3}{|c|}{6} & \multicolumn{3}{|c|}{7} & \multicolumn{3}{|c|}{8} & \multicolumn{3}{|c|}{9} \\
\hline & III & IV & $\mathrm{V}$ & III & $\mathbf{N}$ & $\mathrm{v}$ & III & IV & $\mathbf{v}$ & III & $\mathrm{IV}$ & $\mathrm{V}$ & III & $\mathrm{N}$ & $\mathrm{V}$ & III. & IV & $\mathrm{v}$ & III & IV & $v$ & III & $\mathrm{IV}$ & $V$ \\
\hline $\begin{array}{l}\mathbf{A} \\
\mathbf{B} \\
\mathbf{C} \\
\mathbf{D} \\
\mathbf{E} \\
\mathbf{F} \\
\mathbf{G} \\
\mathbf{H} \\
\mathbf{I}\end{array}$ & 4 & 3 & $\begin{array}{l}2 \\
1 \\
1 \\
1\end{array}$ & $\begin{array}{c}20 \\
1 \\
2 \\
2 \\
2 \\
2 \\
12\end{array}$ & $\begin{array}{c}1 \\
14 \\
1 \\
13 \\
2 \\
1 \\
3\end{array}$ & $\begin{array}{r}1 \\
3 \\
11 \\
\\
14 \\
8 \\
4\end{array}$ & $\begin{array}{l}2 \\
1\end{array}$ & 4 & $\begin{array}{l}2 \\
4 \\
1\end{array}$ & 1 & & 1 & 1 & & & $\begin{array}{l}1 \\
3 \\
1 \\
3 \\
1 \\
2 \\
9\end{array}$ & $\begin{array}{l}9 \\
1\end{array}$ & $\begin{array}{l}4 \\
4 \\
4\end{array}$ & $\begin{array}{l}2 \\
1 \\
4\end{array}$ & $\begin{array}{c}11 \\
2 \\
3\end{array}$ & $\begin{array}{c}2 \\
12 \\
1 \\
14 \\
9 \\
1\end{array}$ & 1 & & \\
\hline
\end{tabular}

anal spine, length of pectoral fin, and number of scales of lateral line, are plotted in Figs. $1 \sim 2$ in reference to the body length. Table 1 tabulates the data of 3 to 5 year-old individuals which constitute the majority of the material.

It is to be seen in the figures and tables that the whole material belong to one category which should go as a species. If any splitting could be admitted, it would lead to recognition of any single individual as representing each distinct species. It goes without saying that erection of several species would appear more plausible in case of fewer number of specimens examined.

\section{BIBLIOGRAPHY}

1. Buekker, P. 1857 : Niewe nalezingen op de ichthyologie van Japan. Verhandl. Batav. Genoot, 26.

2. Cuvier, G. and Valenciennes, A. 1829: Histoire naturelle des poissons. 4.

3. Franz, V. 1910: Die japanische Knochenfische der Sammulungen Haberer und Doflein. Abhand. math-phys. Klas. K. Bay. Akad. Wiss., 4.

4. Günther, A. 1860 : Cat. Fish. Brit. Mus., 2.

5. Hilgendorf, F. 1880: Ueber die japanischen Sebastes. Sitzungs-Ber. Ges. nat. Freunde, Berlin. 
6. Jordan, D. S. and Evermann, B. W. 1898: The fishes of North and Middle America. Bull. U. S. Nat. Mus. 47-2.

7. Jornan, D. S. and Hubss, C. L. 1925 : Record of fishes obtained in Japan, 1922. Mem. Car. $=$ Mus. 10-2.

8. Jordan, D. S. and Metz, C. W. 1913. A catalogue of the fishes known from the waters of Korea. Ibid. 6-2.

9. JordAN, D. S. and SwYone, J. O. 1901: List of fishes collected in 1888 and 1885 by Pierre Louis Jouy and preserved in the United States National Museum, with description of six now species. Proc. U. S. Nat. Mus. 23-1235.

10. Jordan, D. S. and Starks, E. C. 1904: A review of the scorpaenoid fishes of Japan. Ibid. $27-1351$

11. Jopdan, D. S. and Trompson, W. F. 1914: Record of fishes obtained in Japan in 1911. Mem. Car. Mus. 6-4.

12. NYзтrö̆, E. 1887 - Redogörelse för den Japaniska Fishamlingen i Upsala Univasitates Zoologiska Museum. Bihang till K. Svensk. Vet-Akad. Handl., Band 13-4.

13. Schmidr, P. 1931: Fishes of Japan collected in 1901. Trans. Pacif. Comm. Acad. Sci. U. S. S. R. 2.

14. SNYDer, J. O. 1912: Japanese shore fishes collected by the United States Bureau of Fisheri,s Steamer "Albatross" expedition of 1906. Proc. U. S. Nat. Mus. 42-1969.

15. Steindachner, F. and Dönerleiv, L. 1887: Beiträge zur Kentnis der Ffsche Japans. Denksch. Kais. Akad. Wiss. 4.

16. TANAKA, S. 1931: On the distribution of fishes in Japanese waters. Jour. Fac. Sci. Imp. Univ. Tokyo. 3-1.

17. Temminck, C. J. and Schlegel, H. 1850: Siebold's Fauna Japoniea, Pisces. 